\section{Reproductive Freedom, Torture and International Human Rights: Challenging the Masculinization of Torture, By Ronli Sifris}

\author{
Published by Routledge (ISBN: 978-0-415- \\ 65963-5)
}

\section{Nora Sveaass, Associate Professor*}

The title of the book could not be clearer about its key message. In the words of the author, it aims to "contribute to a feminist conceptualization of international human rights by examining restrictions on reproductive freedom through the lens of the right to be free from torture and CIDT [Cruel, Inhumane or Degrading Treatment]" (p8). Sifris' book draws attention to the grave reality surrounding women's reproductive freedom in numerous countries and, in particular, the severe restrictions on abortions and the practice of involuntary sterilizations. The author affirms how inhumane and dangerous it is for international law to overlook women's choices in relation to their own bodies, and the consequences this may have, with many women suffering or dying because of lack of protection. The important question, which is

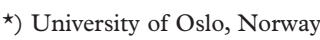

not only raised but discussed in depth, is: how the prohibition against torture can actively be applied in this context?

The author presents a very comprehensive overview of the prohibition against torture, both in international human rights laws and in regional human rights legislation. Rich examples of jurisprudence and the changes in jurisprudence with regard to reproductive rights are provided, with reproductive rights being defined as those related to pregnancy and childbirth. Despite the importance of a whole range of existing legal provisions regarding torture, priority is given to the UN Convention against Torture, in particular the definition of torture in Article 1, and the jurisprudence of the UN Committee against Torture, including a useful historical overview. This is done in a convincing way as the author "deconstructs" the definition in the convention through a step-by-step analysis of its four main elements and how these can relate to violations on reproductive freedom. The discussion is both conceptually sound and provides substance, including appropriate reference to jurisprudence, recommendations presented to States as part of periodic reporting and the Committee's General Comments. Despite the jurisprudence based on decisions in individual complaint cases being fairly limited, there are a number of very clear concluding observations by the Committee against Torture ('COB'), on restrictions on abortion (for instance in the COBs to Peru in 2006, to Nicaragua in 2009, to Paraguay in 2011 and to Ireland also in 2011), and on involuntary sterilizations (COBs to Czech Republic in 2004 and 2012, to Peru in 2006

${ }^{\mathrm{i}}$ UN CAT (2008). General comment No. 2 on article 2 of the Convention against Torture. AVailable from: http:/ www2.ohchr.org/english/bodies/cat/GC2.htm 
etc.). The references that are made to General Comment No. $2^{\mathrm{i}}$ on the obligation of states to prevent torture and ill-treatment, and the inclusion of the term 'reproductive decision' relating to women (paragraph 22), firmly position this form of violence as being under the Convention. The author clearly acknowledges the importance of the concrete steps taken by many of international bodies and the Committee against Torture in strengthening the reproductive rights of women by pointing out state responsibility under the Convention.

The book's review of both the definition and its elements (that is, severe pain and suffering, intentionality, purpose: discrimination and public official) is remarkably thorough as well as challenging and eyeopening. Serious limitations to women's decisions over their bodies can mean severe pain and suffering and the principle of intentionality is understood in this context. In particular, an understanding of the discriminative element as an example of purpose is clearly explored and supported by cases and principles. The public official element of the definition is fulfilled by the fact that decisions taken over women's reproductive rights are more often than not related to legal provisions in a country, or even when non-state actors are involved, lack of due diligence and failure to protect on the part of the state. How this relates to the definition of torture also allows for the analysis of examples and situations that may fall under the concept of torture and thereby an accompanying state obligation to prevent. A number of strong examples of the injustice women have been exposed to are provided, such as denial of abortion on very young girls who have become pregnant after rape, including by their own fathers, denial of ending pregnancy even when life is at stake, and sterilization forced upon women for reasons of racial discrimination or political oppression.

An interesting discussion regarding the condition of "powerlessness" often associated with torture is also included which builds on the work of Burgers and Danelius, as well as M. Nowak, all of whom have highlighted the importance of the key difference between being in a situation where there is some power to escape and where there is not. This element of powerlessness is discussed and analysed by the author in the same way as the formal elements of the definition of torture. It is a very interesting discussion and arguments relating to domestic violence and the definition of torture and CIDT are brought in. However, it was surprising that there was no further discussion about the problematic aspects of the powerlessness concept, especially since it has been challenged from a feminist point of view. Copelon, for example, is concerned that a focus on powerlessness risks diminishing the plight of battered women vis-a-vis men in detention, implying that the former have a greater ability to leave an environment where there are tortured. It also risks bringing back the blame on the woman for her abuse. ii The discussion is nevertheless valuable and contains substantial and relevant arguments as well as cases.

As a former member of the Committee against Torture, who has taken an active part in the discussions surrounding these issues during the period in which the analysis covers, I found the review and analysis of primarily the four elements of the definition to be an extraordinarily valuable and

\footnotetext{
ii Copelon R, Gender Violence as Torture: The

Contribution of CAT General Comment No. 2, 11 N.Y.

City L. Rev. 229 (2008).

Available from: http://academicworks.cuny.edu/clr/vol11/ iss $2 / 7$
} 
stimulating contribution to the field in general, and in particular to the field of reproductive rights and international law. That said, this publication should not stand alone, but be a springboard for further thinking and discussion on the issue. The mapping exercise carried out in the book importantly includes highlighting the gaps, silences, and vagueness that continue to surround violence and abuse in connection with reproductive rights and, in particular, restrictions on abortion and involuntary sterilization procedures. This also brings attention to rape as a form of violence against women and as a form of human rights violation. It also furthers the discussion about when and under what conditions international human rights law considers rape to be torture. The discussion on this topic has developed over the last few years and the contribution also from the Committee against Torture on this issue is significant. ${ }^{\text {iii }}$ The book represents a very important summary of the process that has taken place with regard to women's rights, serious human rights abuses and in particular sexual, gender-based violence over the last 20 years. In so doing, it contributes to the call for how women's lived experiences of torture should be defined as just that: torture.

The book's reach - or its potential impact - goes further than an analysis of the specific points raised - it is a feminist analysis of international law, highlighting the fact that torture has been, and usually still is, described and discussed in a gendered way, that is, as a mainly male-related problem, and specifically, as something that happens

iii Gaer FD. Rape as a form of torture: the experience of the Committee against Torture. Cuny Law Review 2012;15:293-308. Available from: http://www. cunylawreview.org/wp-content/uploads/2013/08/Gaer_ Rape-as-a-Form-of-Torture.pdf to men in detention. The author argues that international law reflects this exclusionary and masculinized understanding of torture and, as such, serious violations may fall under the radar and threats to women's lives and well-being may fall short of the scrutiny otherwise given to acts of torture or CIDT. In light of this, the book represents a very important contribution to the field and it opens up a larger debate about prevention, protection and accountability with regard to women, reproductive rights and torture. Moreover, it is a book which gives insight and perspective to all those involved in working with human rights and prevention of all genders and all ages.

'Reproductive Freedom, Torture and International Human Rights: Challenging the Masculinization of Torture' is not only worth reading, but worth studying in depth. It succeeds in its aim to analyze "the meaning of torture and CIDT under international human rights law with a view to conceptualizing these terms so as to include issues of disproportionate concern to women, particularly restrictions of reproductive freedom" ( $\mathrm{p} 4)$. Anyone trying to understand, study, or work with international law should read this book in order to conceptualize the gendered nature of it and in order not to discount half the world's population. Furthermore, this book challenges the international legal system, which was developed primarily by men and does not properly address women's lived experiences. It is a timely and a very important book.

\section{Acknowledgements:}

Thanks to Nora Uhrich, Fullbright Student at the University of Oslo for constructive conversations about the book. 